$$
\text { DOE/PC/79798- - T/7 }
$$

DOE/PC/79798--T17

DE92 007852

\title{
LIMB DEMONSTRATION PROJECT EXTENSION
}

QUARTERLY REPORT NO. 18

FOR THE PERIOD - AUGUST, SEPTEMBER, AND OCTOBER, 1991

December 16, 1991

DOE Agreement No.: DE-FC22-87PC79798

B\&W CRD Agreement No.: CRD-1171

\author{
Prepared by: \\ Babcock \& Wilcox \\ a McDermott Company
}

\section{DISCLAIMER}

This report was prepared as an account of work sponsored by an agency of the United States Government. Neither the United States Government nor any agency thereof, nor any of their employees, makes any warranty, express or implied, or assumes any legal liability or responsibility for the accuracy, completeness, or usefulness of any information, apparatus, product, or process disclosed, or represents that its use would not infringe privately owned rights. Reference herein to any specific commercial product, process, or service by trade name, trademark, manufacturer, or otherwise does not necessarily constitute or imply its endorsement, recommendation, or favoring by the United States Government or any agency thereof. The views and opinions of authors expressed herein do not necessariiy state or reflect those of the United States Government or any agency thereof.

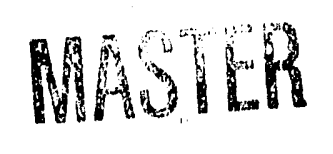


DISCLAIMER.............................. 1

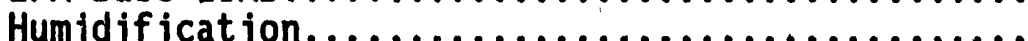

Phase I - Design \& Permitting...................

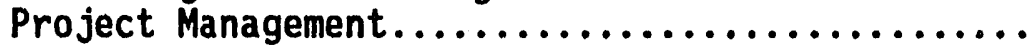
Cools ide Management \& Reporting........... LIMB Extension Management \& Reporting......

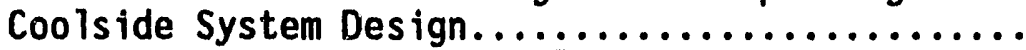
Testing Program Development............

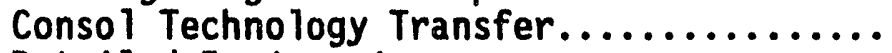

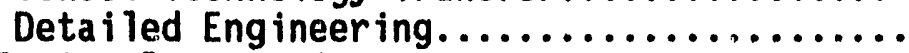

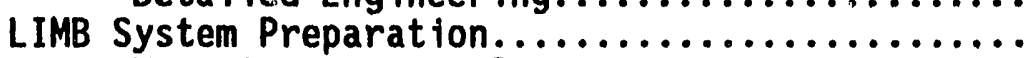

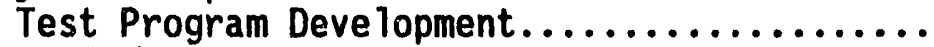

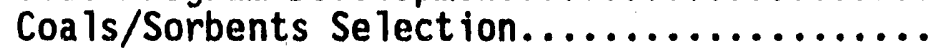

Permitting \& Licensing.....................

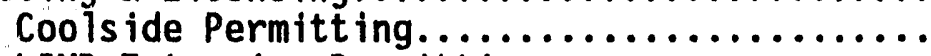
LIMB Extension Permitting.

Phase II, Coolside \& LIMB Construction, Start-UP.

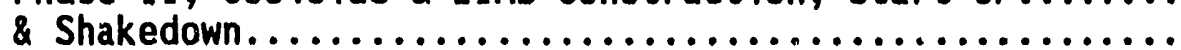

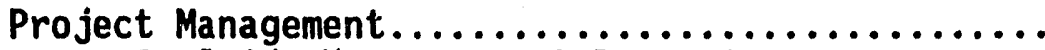
Cools ide Management \& Reporting............. LIMB Extension Management \& Reporting....... Coolside Construction \& Start-Up................

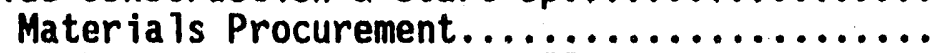
Sorbent Feed System Installation...........

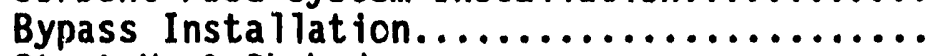

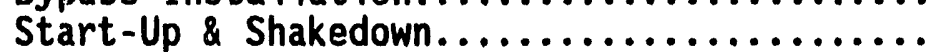

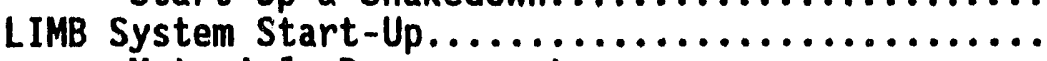

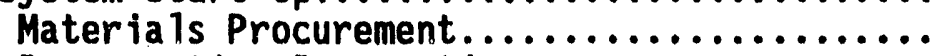

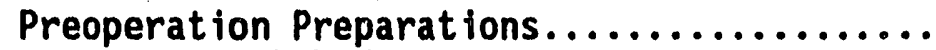
Start-Up \& Shakedown. 


\section{TABLE OF CONTENTS}

Section

Page

4.3 Phase III - Operation, Data Collection, Reporting

\& Disposition................................ 12

4.3.1

4.3.1.1

Project Management...................... 12.

4.3.1.2

4.3.2

4.3.2.1

4.3.2.2

4.3.2.3

4.3.2.4

4.3.3

4.3.3.1

4.3.3.2

4.3.3.3

Coolside Management \& Reporting........... 12

LIMB Extension Management \& Reporting....... 12

Coolside Operation \& Evaluation............... 12

Opt imization........................ 12

Testing Program...................... 13

Evaluation \& Reporting................. 13

Disposition........................ 13

LIMB Extension Operation \& Evaluation........... 13

Testing Program........................ 13

Evaluation \& Reporting................. 13

$5.5 .0 \quad$ PLANNED ACTIVITIES ........................... 15

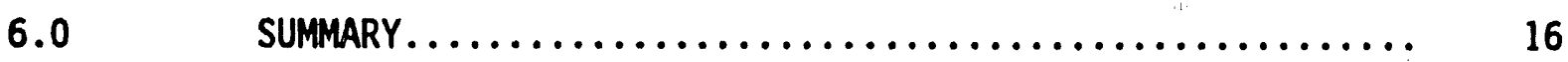

7.0

REPORT DISTRIBUTION LIST. 


\section{DISCLAIMER}

This report was prepared by The Babcock \& Wilcox Company pursuant to a cooperative agreement partially funded by the U.S. Department of Energy and neither the Babcock \& Wilcox Company, nor any of its subcontractors nor the U.S. Department of Energy, nor any person acting on behalf of either:

(a) Makes any warranty or representation, express or implied, with respect to the accuracy, completeness, or usefulness of the information contained in this report, or that the use of any information, apparatus, method, or process disclosed in this report may not infririge privately-owned rights;

or

(b) assumes any liabilities with respect to the use of, or for damages resulting from the use of, any information, apparatus, method or process disclosed in this report.

Reference here in to any specific commercial product, process, or service by trade name, trademark, manufacturer, or otherwise, does not necessarily constitute or imply its endorsement, recommendation, or favoring by the U.S. Department of Energy. The views and opinions of authors expressed herein do not necessarily state or reflect those of the U.S. Department of Energy. 


\subsection{EXECUTIVE SUMMARY}

The LIMB Demonstration Project Extension (DOE Agreement No. DE-FC22-87PC79798) progress for August, September, and October, 1991, was made in cont inuation of Phase III, Operation, Data Collection, Reporting and Disposition.

Project Management activities focused on expediting the completion of the Coolside Topical Report and coordinating and scheduling the site demobilization and restoration at the Edgewater Station..

Phase I, Design and Pernitting, activities are complete.

Phase II, Coolside and LIMB Construction Start-up and Shake-down, activities are comp lete.

Phase III, Operation, Data Collection, Reporting and Disposition, activities were focused on revising the draft of the Coolside Topical Report, completing the LIMB Extension testing program and beginning site demobilization and restoration.

Consol completed work on revising the draft of the Coolside Topical Report in light of B\&W and DOE comments.

LIMB Extension testing concluded with commercial calcitic hydrated lime and 1.6 percent sulfur coa?.

Radian Corporation continued to monitor emissions and to implement the environmental monitoring plan.

Site demobilization began in earnest following the completion of the LIMB Extension tests on August 30, 1991. The unit came off line for a scheduled outage on September 20, 1991 which allowed for the major restoration activities to begin. 


\subsection{INTRODUCTION}

As per the Cooperative Agreement No. DE-FC22-87PC79798 dated June 25, 1987, the following quarterly report has been prepared for Phiases I, II, and III of the LIMB Demonstration Project Extension. This DOE project includes "Ccolsiae" technology and LIMB mult iple sorbent: injection. The period covered by this quarterly report is August, September and October 1991. This report represents the eighteenth three month period of the project.

The subject of this report is progress during the quarter for Phase I - Design and Permitting, Phase II - Coolside/LIMB Construction, Start-Up and Phase III Operation, Data Collection, Reporting and Disposition.

Under Phase I, all activities are complete.

Under Phase II, all activities are complete.

Under Phase III, Task 1, A detailed schedule was developed for site demobilization and restoration. Task 2 activities included Consol complet ing the revisions to the Coolside Topical Report in light of B\&W and DOE comments. Task 3 activities continued with the LIMB testing and the start of site demobilization and restoration. 


\subsection{PROJECT DESCRIPTION:}

\subsection{BACKGROUND}

\subsubsection{EPA Base LIMB}

The DOE LIMB Demonstration Project Extension is a continuation of the EPA Limestone Injection Multistage Burner (LIMB) Demonstration.

The EPA LIMB program was initiated in 1981, a lthough work in related areas had been conducted by EPA and others prior to that time. The LIMB program is structured to provide an understanding of the controlling factors in the LIMB process and to establish a basis for private sector commercialization of the technology. EPA ultimately expects to show that LIMB is a low cost control technology capable of producing moderate $\mathrm{SO}_{\mathrm{x}}$ and $\mathrm{NO}_{\mathrm{x}}$ control (50-60 percent) with applicability for retrof it to the major portion of the existing coal-fired boller population.

The current EPA Wa11-Fired LIMB Demonstration is a four-year project that includes design and installation of a LIMB system at the 105-MW Unit 4 boiler at Ohio Edison's Edgewater Station in Lorain, Ohio. The project plan calls for a full year of operating and testing to demonstrate its capabilities. In addition to the EPA the major project participants are the State of Oh10, Ohio Edison, and Babcock \& Wilcox (B\&W).

The basic goal of the LIMB demonstration is to extend LIMB technology deve lopment to a full-scale application on a representative wall-fired utility boiler. The successful retrof it of LIMB to an existing boiler is expected to demonstrate that (a) reductions of 50 percent or greater in $\mathrm{SO}_{x}$ and $\mathrm{NO}_{x}$ emissions can be achieved at a fraction of the cost of add-on FGD systems, (b) boiler reliability, operability, and steam production can be maintained at levels existing prior to LIMB retrofit, and (c) technical difficulties attributable to LIMB operation, such as additional slagging and fouling, changes in ash disposal requirements, and an increased particulate load, can be resolved in a cost-effective manner. The primary fuel to bo used will be an ohio bituminous coal having a nominal sulfur content of 3 percent or grater.

The demonstration project consists of several distinct phases: a preliminary phase to develop the LIMB process design applicable to the host boiler, a construction and start-up phase, and an operating and evaluation phase. The first major activity, the development of the Edgewater LIMB design, was completed in January 1986 and detailed engineering is now complete. Major boiler-related components were installed during a September 1986 boiler outage. Start-up activities began in March of 1987 with tuning of the low NO burners. Sorbent injection activities were under way as of July 1987. 


\subsubsection{HUMIOIFICATION}

As a modification to the Base LIMB work, the applicability of flue gas humidification as a supplement to the LIMB process for the purpose of improving particulate collection and $\mathrm{SO}_{2}$ capture efficiencies is being evaluated. The reason for this investigation is that the LIMB process may cause some degradation in the performance of electrostatic precipitators. This degradation will be the result of three factors:

1. The dust loading to the ESP will more than double.

2. The particle size distribution of the injected sorbent may be finer and, therefore, more difficult to capture than the normal flyash from coal combustion.

3. The sorbent has chemical affinity for $\mathrm{SO}_{3}$. This will result in a lowering of the acid dew point and consequently increasing of the resistivity of the ash.

Humidification may provide low-cost option that would restore ESP performance on LIMB retrofitted boilers. In addition, humidification of flue gas has been shown to increase $\mathrm{SO}_{2}$ capture by rendering sorbent particles more react ive. The amount of humidification required to improve $\mathrm{SO}_{2}$ capture efficiency and to restore ESP performance may present operational problems. The EPA Humidification program will result in a humidification system design aimed at minimizing operational problems and maximizing $\mathrm{SO}_{2}$ capture and particulate removal enhancement. The effect of humidification will be determined during the EPA LIMB Demonstration testing at Ohio Edison's Edgewater Unit 4.

The incentives to humidify to as close an approach to saturation as possible are:

1. Particulate emissions from the small ESP's designed for burning highsulfur coal can possible be kept in compliance without the high cost of additional particulate collection area.

2. Additiona $1 \mathrm{SO}_{2}$ removal can be achieved by taking advantage of the unreacted sorbent from the boiler.

However, the extent of $\mathrm{SO}_{2}$ removal will be strongly dependent upon how much the flue gas temperature is reduced. The risk of scaling, pluggage, and other operating problems also increase sharply as the gas temperature approaches adiabatic saturation.

It is because of the risk of scaling and pluggage that the humidification demonstration is being carried out in a bypass flue. With the humidifier installed in a bypass flue, initial operating problems will not interrupt boiler operation. Various operating conditions at closer approaches to saturation can be tried without fear of shutting down the boiler should a wall deposition problem develop. This bypass will be used for EPA humidification work ard for the DOE LIMB and Coolside process demonstrations, of which humidification is an integral part. Funding for the bypass will be provided as part of the DOE LIMB Demonstration Project Extension. 


\subsection{DOE LIMB DEMONSTRATION PROJECT EXTENSION OVERVIEW}

The purpose of the DOE LIMB Demonstration Project Extension is to extend the data base on LIMB technology and to expand DOE's list of Clean Coal Technologies by demonstrating the coolside process as part of the project.

The main objectives of this project are:

1. To demonstrate the general applicability of LIMB technology by testing 3 coals and 4 sorbents (total of 12 coal/sorbent combinations) at the Ohio Edison Edgewater Plant.

2. To demonstrate that Coolside is a viable technology for improving precipitator performance and reducing sulfur dioxide emissions while acceptable operability is maintained.

To achieve these objectives, B\&W will perform a three-phase project consistent with the DOE PON:

PHASE I: DESIGN AND PERMITTING

PHASE II: CONSTRUCTION AND START-UP ("SHAKEDOWN")

Phase II A: Site Preparation and Long-Lead Time Item Procurement.

Phase II B: Coolside/LIMB Construction, Start-Up and Shakedown

Phase III: OPERATION, DATA COLLECTION, REPORTING AND DISPOSITION

Since the DOE LIMB Demonstration Project Extension is a continuation of an ongoing EPA Project, it was necessary at the start of the project to divide Phase II into IIA and IIB to avoid project schedule de lays on both projects. Phase IIA entailed certa in site preparation and long-lead time item procurement activities which had to take place before actual construction and start-up could commence. Most of these activities were completed during the boiler outage originally scheduled by Ohio Edison from September 28, 1987 through December 20, 1987 to perform major turbine ma intenance. The outage actually lasted unt 11 late January 1988. It provided the opportunity to perform the flue gas duct revisions needed for the tie-in of the bypass duct once its construction was complete.

Phase IIB consisted of Coolside/LIMB Construction, Start-up and Shakedown activities. This Phase started on August 26, 1987, one month prior to the outage "window". Time was needed to perform pre-outage activities and to assure that sutage construction work was organized and ready to begin on scheur ia. Phase IIB construction consisted primarily of the bypass flue, where the humidifier is installed, and the coolside feed system.

Originally the bypass was to be completed in time to allow EPA humidification testing to be performed during the last four months of Base LIMB operation. However, preliminary LIMB test results indicated the electrostatic precipitator (ESP) performance suffered as a result of sorbent injection. 
Humidification is now considered necessary to improve ESP performance and to allow long term LIMB testing to occur. LIMB and Humidification testing will cont inue simultaneously after humidifier construction is complete. Thus, a de lay in EPA LIMB testing is necessary until the bypass is ready.

EPA LIMB testing with humidification was scheduled to begin in July 1988. Once EPA testing is complete, Phase III of the DOE LIMB Demonstration Project Extension is scheduled to begin operations on July 17, 1989 by testing the Coolside process for a four (4) month period. Afterwards, the LIMB Extension testing, which is scheduled to run for twelve (12) months, will begin.

For the purposes of this quarterly report which includes updated schedule information, Phases IIA and IIB activities have been combined into Phase II as was done in quarterly Report Number 4. Phase IIA is considered to be complete.

Figures 1, 2, and 3 represent the revised schedules for Phase I, Phase II (combined o.'ginal Phases IIA and IIB) and Phase III respect ively. The DOE LIMB Demonstration Project Extension schedule has been lengthened by three (3) months, from a total of forty-three (43) months to forty-six (46) months, because the start of Coolside testing has been delayed to complete EPA LIMB testing.

A complete Statement of Work is included in Section III, Project Description of the first quarterly report for the project, dated September 15, 1987 . It provides the reader, who is not familiar with the project, a complete description of the tasks and subtasiks to be undertaken. 


\subsection{PROJECT STATUS}

The period covered by this project Quarterly Report Number 18 is August, September, and October, 1991. Progress will be discussed on a task basis for each of Phases I, II and III.

\subsection{PHASE I - DESIGN AND PERMITTING (WBS 1.1)}

Phase I entails project management, Coolside system design, LIMB system preparation and permitting activities.

\subsubsection{Task 1 - Project Management (WBS 1.1.1)}

\subsubsection{SUBTASK 1.1 - COOLSIDE MANAGEMENT AND REPORTING (WBS 1.1.1.1).}

The activities under this subtask are complete.

4.1.1.2 SUBTASK 1.2 - LIMB EXTENSION MANAGEMENT AND REPORTING (WBS 1.1.1.2). The activities under this subtask are complete.

\subsubsection{Iask_2 - Coolside System Design (WBS 1.1.2)}

Coolside system design includes sorbent selection, pilot performance tests and detailed engineering.

\subsubsection{SUBTASK 2.1 - TEST PROGRAM DEVELOPMENT (WBS 1.1.2.1).}

The activities under this subtask are complete.

4.1.2.2 SUBTASK 2.2 - CONSOL TECHNOLOGY TRANSFER (WBS 1.1.2.2).

The activities under this subtask are complete.

4.1.2.3 SUBTASK 2.3 - DETAILED ENGINEERING (wbs 1.1.2.3). The activities under this subtask are complete.

\subsubsection{Task 3 - LIMB System Preparation (WBS 1.13)}

The LIMB system preparation activities are designed to update the current LIMB system documentation in use for the EPA testing.

4.1.3.1 SUBTASK 3.1 - TEST PROGRAM DEVELOPMENT (WBS 1.1.2.1) The activities under this subtask are complete.

4.1.3.2 SUBTASK 3.2 - COALS/SORBENTS SELECTION (WBS 1.1.3.2) The activities under this subtask are compete. 


\subsubsection{Iask 4 - Permitting and Licensing (WBS 1.1.4)}

Permitting activities are focused on waste characterization to develop the information necessary to fulfil permit requirements. In addition, efforts to fulfill project environmental monitoring requirements are addressed in this task.

\subsubsection{SUBTASK 4.1 - COOLSIDE PERMITTING (WBS 1.1.4.1)}

The activities under this subtask are complete.

4.2 PHASE II COOLSIDE 7 LIMB CONSTRUCTION, START-UP AND SHAKEDOWN WBS 1.2).

Phase II consists of actual construction of the Coolside system, including the humidifier, followed by start-up and shakedown activities which make the system ready for the testing program.

\subsubsection{Task 1-Project Management (WBS 1.2.1)}

Project management activities perta in to both the Coolside and LIMB construction, start-up and shakedown efforts.

\subsubsection{SUBTASK 1.1 - COOLSIDE MANAGEMENT AND REPORTING (WBS 1.2.1.1).}

The activities under this subtask are complete.

4.2.1.2 SUBTASK 1.2 - LIMB EXTENSION MANAGEMENT AND REPORTING (WBS 1.2.1.1).

The activities under this subtask are complete.

\subsubsection{Iask2-Cools ide Construction \& Start-Up (WBS 1.2.2)}

Coolside start-up and construction activities include materials procurement during construction plus installation of the Coolside sorbent feed system and humidifier bypass system.

\subsubsection{SUBTASK 2.1 - MATERIALS PROCUREMENT (WBS 1.2.2.1).}

The activities under this subtask are complete.

4.2.2.2 SUBTASK 2.2 - SORBENT FEED SYSTEM INSTALLATION (WBS 1.2.2.2). It is noted that a significant portion of the existing LIMB sorbent feed system was used for Coolside. The equipment includes the LIMB sorbent storage silo and the pneumatic conveying system that brings sorbent to the feed silo. The present feed silo and the dilute phase metering and pneumatic conveying systems up to the present distributor bottles was utilized for the Coolside demonstration. 
The Coolside sorbent feed sysiem installation includes the installation of new piping from the end of the present dilute phase pneumatic conveying system to a point in the bypass duct upstream of the humidifier. This piping includes another distributor bottle to assure good sorbent distribution in the humidifier. The distributor bottle allows multiple injection points into the duct as opposed to a sirgle injection point.

A second system that is considered part of Cools ide equipment requirements is the ash recycle system. This system will recycle a portion of the ash collected in the electrostatic precipitators back to the inlet of the humidifier bypass duct. It is made up of an ash pneumatic conveying system, delivery piping to the inlet of the bypass duc ${ }^{+}$. and another distributor bottle.

The activities under this subtask are complete.

4.2.2.3 SURTASK 2.3 - BYPASS INSTALLATION (WBS 1.2.2.3). The bypass duct construction was completed and the duct was placed into service during EPA LIMB testing with humidification.

The activities under this subtask are complete.

4.2.2.4 SUBTASK 2.4 - START-UP AND SHAKEDOWN (WBS 1.2.2.4). The activities under this subtask are complete.

\subsubsection{Iask 3 - LIMB System Start-Up (WBS 1.2.3)}

Effort under this task was minima 1, since the LIMB system was operational for the EPA base LIMB program prior to this testing. Nevertheless, some preparation and change over was necessary in shifting from the DOE Coolside testing to the LIMB Demonstration Extension Testing.

4.2.3.1 SUBTASK 3.1 - MATERIALS PROCUREMENT (WBS 1.2B.3.1). The coa Is anic sorbents were procured under this subtask. Activities included arranging transportation, scheduling and expediting deliveries, storage at the site, verifying that materials meet specifications, etc.

The objective of this subtask was to finalize the procurement of three (3) different coals and four (4) different sorbents.

The activities under this subtask are complete.

4.2.3.2 SUBTASK 3.2 - PREOPERATION PREPARATIONS (WBS 1.2B.3.2). Activities under this subtask included inspection of equipment and instrumentation, and repair or replacement of system components where necessary prior to beginning LIMB Extension testing.

The sorbent feed system delivery points needed to be changed from the Cools ide injection area upstream of the humidifier back to the upper regions of the boiler for LIMB operations. 
The objective of this subtask was to prepare the LIMB equipment for continuous operaticin after Cooiside testing was complete.

The work scope of this task was revised to include an upgrade to the 1 ime feed system involving material and labor costs. The upgrade significantly increased the feed system reliability and capacity for the LIMB Extension program.

The scope of work involved rebuilding a used Fulle -K inyon lime pump from another B\&W project to replace one of the two rotary air-locks on the discharge side of the Acrison feeders. The weight of the pump and the additional density of 1 imestone required reinforcement and load distribution additions to the building structure.

The activities under this subtask are complete.

4.2.3.3 SUBTASK 3.3 - START-UP AND SHAKEDOWN (WBS 1.2B.3.3). Start-Up and check-out of any equipment or instrumentation that was repaired or replaced during the previous subtasks were done. Since the first series of coal and sorbent combinations that were tested used the EPA Base LIMB coal, little or no shakedown of the coal feed system and burner system was necessary. Later in the project when the coal was changed, shakedown was necessary as is typical with any coal change at the plant.

The objective of this subtask was to begin operation of the LIMB system to verify system capability for continuous operation.

The activities under this subtask are complete. 


\subsection{PHASE III - OPERATION, DATA COLLECTION, REPORTING AND DISPOSITION}

(WBS 1.3)

Phase III entails the actual testing of the Coolside process for an approximate four (4) month period followed by an additional twe lve (12) month period of LIMB Demonstration Project Extension testing. Phase I - Design and Permitting and Phase II - Construction and Start-up will have been substantially completed by the provided scheduled start date of Phase III providing the ground work to beg in testing.

\subsubsection{Task 1-Project Management (WBS 1.3.1)}

Project management activities pertain to both the Coolside and LIMB Extension operation, data collection, reporting and disposition.

\subsubsection{SUBTASK 1.1 - COOLSIDE MANAGEMENT AND REPORTING (WBS 1.3.1.1)}

A revised draft copy of the Consol Coolside Topical Report was transmitted to the DOE for review and approval.

\subsubsection{SUBTASK 1.2 - LIMB EXTENSION MANAGEMENT AND REPORTING (WBS 1.3.1.2)}

The seventeenth quarterly report covering the period of May, June, and July, 1991, for this project was completed and issued to DOE PETC in September, 1991.

During August, B\&W developed a more detailed schedule for the site restoration work to be done during the October outage.

\subsubsection{Iask 2 - Cools ide Operation and Evaluation (WBS 1.3.2)}

Activities under this task were directed at setting the Coolside operating parameters and demonstrating and evaluating Cools ide technology.

4.3.2.1 SUBTASK 2.1 - OPTIMIZATION (WBS 1.3.2.1). Following the Start-up, which was covered as part of Phase II, B\&W demonstrated that the equipment is capable of operating within the design range. This activity pertained to the Coolside sorbent feed system, the ash recycle equipment and the caustic injection system. Operating characteristics of greatest importance were the sorbent and ash recycle distribution achieved at the inlet to the humidifier and ease of handling of the ash at low approaches to saturation temperature.

The activities under this subtask are complete. 


\subsubsection{SUBTASK 2.2 - TESTING PROGRAM (WBS 1.3.2.2).}

Demonstration of the Coolside process was completed on February 16, 1990.

4.3.2.3 SUBTASK 2.3 - EVALUATION AND REPORTING (WBS 1.3.2.3). Evaluation of the test data generated from the four (4) month test program will include: 1) data reduction and 2) a determination of the overall effectiveness of the tested Cools ide process.

Upon completion of the data evaluation, a Final Report will be written that addresses the technical performance of the Coolside System, and evaluation of the System in terms of its design, capital and operating costs, operational and lia intenance features.

During the first part of the quarter, Consol completed the revisions to the report on Coolside testing in light of B\&W and DOE comments. The report was sent to B\&W for a review and the revised version was transmitted to the DOE for their review and approval.

4.3.2.4 SUBTASK 2.4 - DISPOSITION (WBS 1.3.2.4). After completion of a 11 Coolside testing, the disposition of the sorbent injection system will be determined.

Tre activities under this subtask are complete.

\subsubsection{Task 3 - LIMB Extension Operation and Evaluation}

4.3.3.1 SUBTASK 3.1 - TESTING PROGRAM (WBS 1.3.3.1). Three (3) coals and four (4) sorbents will be tested during an approximate twe lve (12) month period. One promoted sorbent will be tested with the EPA Base LIMB 3.0\% -sulfur coa?.

Each remaining coal/sorbent combination will be tested for approximately one (1) month. The one month of testing will be divided into three (3) distinct test periods - Change-over, Optimization and Cont inuous Operation.

One hundred and twenty (120) hours of I.IMB Extension operation occurred during August. Tests with commercial calcit lic lime as the sorbent were completed while burning both the nominal 3.8 and 1.6 percent sulfur coals. Operation was sporadic, especially during the first half of the month due to reduced demand with the cooler weather.

The LIMB Extension testing program ended in September with LIMB keeping the unit in compliance as Ohio Edison burned off the last of the 3.8 percent sulfur coa 1 in the yard.

4.3.3.2 SUBTASK 3.2 - EVALUATION AND REPORTING (WBS 1.3.3.2). Eva luation of the test data generated from the twe lve (12) month program will include: 1.) data reduction, 2.) a technoeconomic study of test results, and 3.) a determination of the overall effectiveness of the tested LIMB process in achieving the project performance goals. Upoin completion of the evaluation, a detailed report will be prepared. 
Analysis of the data continued as work begins on preparation of the LIMB Extension final report.

4.3.3.3 SUBTASK 3.3 - DISPOSITION (WBS 1.3.3.3). After completion of the LIMB Extension testing, disposal of all equipment installed as part of this contract will be determined during this subtask.

Site demobilization and restoration began in earnest following the completion of the LIMB Extension tests. The unit came off line for the scheduled outage on September 20, 1991. Once the outage began, major activities included:

- Removal of the Coolside caustic tank and the flue gas reheater at the ESP outlet to storage locations.

- Inspection of the ESP to determine whether or not we would have to wash it.

- Scaffolding of the furnace and preparation of tube surfaces for ultrasonic testing.

- Restoration of the dustless unloader to its original configuration. 


\subsection{PLANNED ACTIVITIES}

Planned activities for the next quarter November and December, 1991 and January 1992, will include the completion and release of Phase III Coolside Topical Report by Consol, the completion of site restoration, and preparation of the LIMB Extension finai report.

Radian will complete the final emissiors and environmental monitoring report during the period.

B\&W will complete site demobilization and restoration.

Analys is of the data gathered during testing will continue as well as the preparation of the LIMB final report.

The program costs will be continually monitored and reviewed to insure that final completion costs will be funded. 


\subsection{SUMMARY}

Phase I - Design and Permitting - activities are complete.

Phase II - Construction, Shakedown and Start-up - activities are complete.

Phase III - Operation, Data Collection, Reporting and Disposition - activities cont inued with Consol completing the revisions to the Coolside Topical Report, the completion of LIMB Extension testing, and the start of demobilization and restoration. 


\subsection{REPORT DISTRIBUTION LIST:}

A. Mr. Thomas W. Arrigoni

PETC Technical Project Manager

PM-50, Mail Stop 920-L

U.S. Department of Energy/PETC

P.O. Box 10940

Pittsburgh, PA 15236

B. Mr. William R. Mundorf

Contracting Specialist

AD-21, Mail Stop 900-L.

U.S. Department of Energy/PETC

P.0. Box 10940

Pittsburgh, PA 15236

C. Dr. C. Lowell Miller

HQ Program Manager

FE-24 C-178 GTN

U.S. Department of Energy

Washington, DC 20545

D. Office of Patent Counsel

U.S. Department of Energy

9800 South Cass Avenue

Argonne, IL 60439

E. U.S. Department of Energy/PETC

Office of Technology Transfer

MS-01, Ma11 Stop 58-M205

Pittsburgh, PA 15236

F. Dr. S.N. Roger Rao

Burns and Roe Technical Group, Manager

P.0. Box 18288

Pittsburgh, PA 15236

G. Mr. Charles J. Drummond

PM-40, Mail Stop 920-L

U.S. Department of Energy/PETC

P.0. Box 10940

Pittsburgh, PA 15236

H. Mr. Howard Johnson

Ohio Coal Deve lopment Office

P.0. Box 1001

Columbus, Ohio 43266-0101 


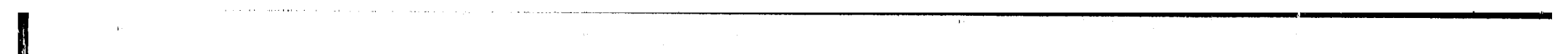

